Іван АРТЬОМОВ,

кандидат історичних наук, доцент, директор ННI євроінтеграційних досліджень ДВНЗ «Ужгородський національний університет»

\title{
ТРАНСФОРМАЦІЙНІ ПРОЦЕСИ У ВИЩІЙ ОСВІТІ ТА НАУЦІ КРАЇ̈ В-4 : ДОСВІД ДЛЯ УКРАЇНИ
}

У статті висвітлюеться спеццифіка інноваційної політики країн Вишеградської четвірки у сфері освіти і науки. Акцентується увага на інтеграції науки, освіти та виробництва як напрямі підвищення конкурентоспроможності Украӥни, інфраструктурному забезпеченні вищих навчальних закладів на основі досвіду крайн Вишеградської четвірки.

Кдючові слова: трансформацчійні процеси, інновації, вищца освіта, Вишеградська четвірка, Украӥна.

В статье раскрывается спеццифика инновационной политики стран Вышеградской четверки в сфере образования и науки. Акцентируется внимание на интеграции науки, образования и производства как направлении повышения конкурентоспособности Украины, инфраструктурном обеспечении высших учебных заведений на основе опьта стран Вышеградской четверки.

Ключевые слова: трансформационные процессы, инновациии, высшее образование, Вынеградскал четверка, Украина.

The article focuses on the specifics of the innovation policy of the Visegrad countries in the field of education and science. The emphasis is on the integration of science, education and production as a way of increasing Ukraine's competitiveness, infrastructure provision of higher education institutions based on the experience of the Visegrad countries.

Keywords: transformational processes, innovations, higher education, Visegrad Four, Ukraine. 
Трансформаційні процеси, що відбуваються в країнах Європейського Союзу під впливом як зовнішніх, так і внутрішніх факторів - явище об'єктивне і діалектично закономірне. Оскільки країни Вишеградської групи є нашими сусідами, їх вплив - суттєвий, особливо на Закарпатський регіон, який виступає з'єднуючою ланкою України з державами ЄС.

Враховуючи тісну співпрацю Ужгородського національного університету з університетами Словаччини, Угорщини, Польщі, Чехії, для нас надзвичайно важдивим є їх досвід 3 впровадження інноваційних форм і методів роботи у вищій освіті та науковій сфері.

Підписання Угоди про асоціацію України з $\mathrm{EC} \mathrm{-} \mathrm{новий}$ крок на шляху інтегрування до европейських освітніх і наукових просторів за рахунок інноваційного розвитку української вищої школи [1]. Зазначимо, що в новому Законі України «Про вищу освіту» ключовою $є$ інноваційна скдадова діяльності вищих навчальних закладів. Зокрема, у статтях $65,66,67,68$ визначено організаційно-правові форми впровадження інновацій, внесено зміни щодо фінансової самостійності вищого навчального закладу.

Мова йде про опрацювання нової філософії освіти освіти, яка б забезпечила комфортне існування дюдини у XXI ст. Західний світ намагається охопити їі Бодонськими деклараціями. I хоча головні напрями розвитку освіти в них визначені досить перспективно, запитань все ще залишається більше, ніж відповідей. Проблема загальної філософії освіти поступово утверджується як головна проблема сучасної світової освітньої політики.

Аналіз досвіду впровадження сучасних технодогій навчання засвідчуе, що інноваційні процеси у вищій освіті сприяють не дише істотному підвищенню теоретичної та практичної підготовки студентів, слухачів, а й насамперед методологічній переорієнтації закладів освіти на особистість, стають основою нової філософії освіти.

Для України інноваційний потенціал вищої школи може й має стати ресурсом для модернізаційного прори- 
ву щодо розвитку високотехнологічних галузей економіки, перспективних наукових напрямів, формування сучасних соціально-культурних стандартів життя.

\section{Інституційно-правове забезпечення інноваційної діяльності у вищій освіті та науковій сфері}

Найважливішими джерелами інформації, що стосуються інновацій та інноваційності підприємств країн Европи, вважаються такі:

$>$ Community Innovation Survey (CIS) [2] - міжнародна програма статистичних досліджень інновацій, що здійснюеться з ініціативи та під егідою Европейської Комісії;

European Innovation Scoreboard (Европейська таблиця результатів у сфері інновацій) [3]. - містить показники інноваційності, що стосуються таких аспектів, як людські ресурси для науки і техніки, видатки на діяльність у сфері досліджень та розвитку, патентна діяльність та ін. На основі цих показників Свропейською Комісією був розрахований «інтегральний показник інноваційності», який використовується для визначення ефективності інноваційної діяльності країн-чденів СС;

Европейський звіт з інноваційності - документ, який показує, на якому рівні інноваційності перебуває кожен член ЕС та які кроки він повинен зробити, щоб підвищити ефективність інновацій.

У 2000 році у країнах Вишеградської групи були прийняті документи у сфері інноваційної політики (Угорщина, Польща, Словаччина, Чехія), метою яких є орієнтація цих країн на науково-технічний та інноваційний розвиток. У цих документах висвітлюються основні напрями інноваційних стратегій і програми розвитку націонадьних інноваційних лідерів на базі великих підприємств, холдингів, високотехнологічних виробництв, які мають пріоритетне значення для формування національної моделі промислового росту. 


\section{Словаччина}

32007 року уряд Словацької Республіки схвалив низку стратегічних документів з питань науки, досліджень та розвитку, а також технологій та інновацій. Найбільш важдивими є:

1. Довгостроковий план Державної науково-технічної політики на 2015 рік [4].

2. Стратегія впровадження довгострокового пиану державної науково-технічної політики на період з 2015 до 2020 pp.

3. Оновлений довгостроковий план Національної подітики в галузі науки і техніки на 2015 рік (Стратегія Фенікс).

4. Мінерва 1.0 (2005-2010) і Мінерва 2.0 (2011-2015) [5].

5. Інноваційна стратегія Словацької Республіки на період 2007-2013 роки.

6. Інноваційна політика Словацької Республіки на період 2008-2010 роки.

7. Інноваційна політика з 2011 по 2013 рр. у рамках Мiністерства економіки Словацької Республіки [5].

Стратегії, прийняті в країнах B-4, не завжди мають чіткі керівні принципи для директивних органів. Їх фрагментація і затримки в прийнятті зробили інноваційну політику непослідовною і неефективною. Тим не менше, навіть якщо структура стратегічного планування зрозуміла, як у випадку з Польщею, інші проблеми, такі, як відсутність керівництва або забезпечення фінансових ресурсів у досягненні конкретних цілей, можливо, й досі виникають.

Кдючові директивні інституції - Міністерство економіки і Міністерство з питань освіти, науки, досліджень і спорту Словацької Республіки (СР), які мають відносно широку мережу установ. Міністерство економіки відповідає за інноваційну політику, в той час, як Міністерство освіти, науки, досліджень і спорту відповідає за дослідження і розробки.

При Міністерстві економіки діють:

1. Сдовацьке інноваційне енергетичне агентство (SIEA). 
2. Державне агентство з розвитку інвестицій і торгівді (Capio).

3. Словацьке агентство з питань бізнесу (SBA).

4. Інноваційний фонд.

Державні органи при Міністерстві освіти вкдючають у себе:

1. Агентство наукової стипендії (VEGA).

2. Агентство з наукового розвитку.

Урядова рада 3 питань науки, технологій та інновацій $є$ постійним експертним, консультативним та координаційним органом Уряду з питань науки, технологій та інновацій.

Крім того, інші міністерства також покликані сприяти науково-дослідним і дослідно-конструкторським роботам. Наприклад, Міністерство внутрішніх справ і Міністерство оборони має кілька інститутів, що займаються науково-дослідною діяльністю. Міністерство охорони навкодишнього середовища є засновником кількох науково-дослідних інститутів, як от: Словацький гідрометеорологічний інститут, Науково-дослідний інститут водних ресурсів та Державний геологічний інститут. Протягом тривалого часу серед цих основних учасників був низький рівень співпраці та синхронізації дій.

Важливий крок в напрямі більш ефективної координації політики НTI (наука, технологіі, інноваціі) був зроблений в 2013 році з прийняттям науково орієнтованої Стратегії Словацької Республіки (Smart Specialisation Strategy of the Slovak Republic). Цей документ являє собою консенсус, який був досягнутий за участі науковців, підприємців, бізнес-кластерів, регіональних державних структур, структур громадянського суспільства та спільних консультацій із зарубіжними фахівцями Европейської Комісії.

Науково-орієнтована Стратегія (Smart) є новою установкою на створення сучасної системи управдіння політики HTI. Основним органом для управління реалізацією RIS3 є Державна рада 3 питань науки, технологій та інновацій. Постійний комітет Державної ради 3 питань науки, техно- 
логій та інновацій буде створений в якості робочого органу 3 ключових владних питань. Інші міністерства та центральні органи державного управління також братимуть участь у цьому процесі. Існуюча мережа виконавчих установ буде трансформована у два самостійні органи: Агентство 3 досліджень і Технологічне агентство. Вони забезпечуватимуть реалізацію RIS3.

\section{Угорщзина}

У зв'язку з перманентними політичними та соціальними змінами в країні уряду не вдається дотримуватися постійного курсу інноваційної політики, що у свою чергу не дає конкретних зрушень у цій сфері діяльності. Та, незважаючи на це, нинішня політика Угорщини у сфері НTI під назвою «Національна стратегія 3 досліджень, розвитку та інновацій» (2013-2020 pр.) (National Research and Development and Innovation Strategy (2013-2020)) :

$>$ визначає створення регіональних інноваційних систем;

виокремлює основні риси в міжнародному інноваційному середовищі;

пропонує огляд продуктивності НТІ;

підкреслюе сидьні і слабкі сторони, базуючись на показниках за 2011р.;

> обговорює стратегічні варіанти;

представляе бачення і встановлює цілі НТІ.

В Угорщині одним 3 перших регіонів, в якому на основі міжнародного досвіду функціонування РІС була підготовлена стратегія вдосконалення інноваційної системи, була Західна Трансданубія [5]. Ця стратегія була спрямована на середньостроковий десятирічний період, iї метою була підготовка та ефективне управдіння нової РІС та мережі. Їі основні завдання:

створення нових установ для системи інновацій та вдосконалення існуючих, а також їх інтеграцї̈ в мережу; 
підвищення інноваційної діяльності бізнесу через організаційні програми стимулювання інновацій;

забезпечення додаткової підтримки діядьності з виробництва наукомісткої продукції та продукції з високою доданою вартістю.

Прикладом для України може служити те, що для реалізаціївищезазначеної стратегіїбуди створені кількаорганізацій. Координаторами першого етапу реалізації інноваційної стратегії виступили West Pannon Regional Development Council (WPRDC) та West Pannon Regional Development Agency (WPRDA).

В результаті реалізації стратегії та пріоритетної політики уряду Угорщини щодо децентралізації влади в кінці 2004 р. разом з чотирма іншими регіональними організаціями WPRDA заснувала West Pannon Regional Innovation Agency (WPRIA), а вже у першій половині 2005 р. $з$ подальшим об'єднанням була створена West Pannon Regional Innovation Council (WPRIC).

Так, за 13 років прямих іноземних інвестицій у Західній Трансданубії були введені нові технології та нові методи управління, підвищились кваліфікація місцевої робочої сили та рівень інноваційного потенціалу. Завдяки цьому в регіоні, на відміну від інших територій Угорщини, виникди нові організаційні моделі: промислові парки, інноваційні центри та інкубатори, нові форми діяльності підприемств малого та середнього бізнесу, кластерні організації для посилення співпраці тощо.

\section{Польщุа}

У 2006 році польський уряд прийняв (незалежно від СС) Національну стратегію розвитку на 2007-2015 рр. [5]. Цей документ окреслив цілі розвитку Польщі і в той же час дав реальну основу для отримання і використання коштів 3 фондів ЄС. На основі цієї стратегії була прийнята ще одна програма - Принципи підвищення економічної інноваційності на 2007-2013 роки, спрямована на перетворення економіки Польщі в «економіку, засновану на знаннях». 
Нинішня польська інноваційна політика безпосередньо випливає 3 документа під назвою Європа 2020: смартстратегії стійкого та інклюзивного зростання.

Політика НТІ в Польщі в основному розроблена двома міністерствами: Міністерством економіки і Міністерством науки та вищої освіти.

Міністерство науки та вищої освіти, у свою чергу, створило два відомства, відповідальні за підтримку політики НТІ в Польщі:

1. Національний центр досліджень і розвитку (NCBiR), який відповідає за прикладні науки.

2. Національний науковий центр (НКР), який відповідае за фундаментальні науки.

Окрім цільових програм, що підтримують інновації, міністерство також бере на себе основну відповідальність за управління польськими регіональними інноваційними системами (РІC), що спільно фінансуються зі структурних фондів $\mathrm{CC}$, пов'язаних з плануванням інноваційної діяльності в період 2014-2020 pp.

Фонд польської науки також відіграє важдиву роль. Фонд є неурядовою, неполітичною і некомерційною організацією, хоча створюеться і підтримується за рахунок державного бюджету. Його головна мета полягає в підтримці польської науки через різні гранти, призи та стипендії. Він також відповідае за розподіл коштів зі структурних фондів, пов'язаних з системою RTDI.

Згідно з законом «Про науково-дослідні організації», науково-дослідницькими установами є:

науково-дослідні інститути;

> науково-дослідні осередки, центральні лабораторії та інші організації, основним завданням яких є проведення науково-дослідної діяльності.

До основних інститутів, що задіяні в інноваційній діяльності, належать:

1. Міністерство національної освіти РП.

2. Міністерство економіки РП. 
3. Міністерство регіонального розвитку РП (Ministerstwo Rozwoju Regionalnego).

4. Інститут знань та інновацій РП (Instytut Wiedzy i Innowacji).

5. Integris - Об'єднання регіональних інноваційних стратегій (Sie Regionalnych Strategii Innowacji).

\section{Науково-технічні пріоритети}

Основними пріорітетами програми інноваційного розвитку є:

1. Дослідження та розвиток сучасних технологій. За цю сферу відповідає Міністерство науки та вищої освіти (MNiSzW).

2. Стратегія інновацій та ефективності економіки: «Динамічна Польща 2020» (Strategy for Innovation and Efficiency of the Economy: «Dynamic Poland 2020».)

3. Національна програма досліджень [6].

4. Інфраструктура в сфері досліджень та розвитку (відповідальне MNiSzW).

5. Капітал для інновацій (відповідальне - Міністерство економіки (MG)).

6. Інвестиції (відповідальне МG).

7. Поширення інновацій (відповідальне MG).

8. Польська економіка на міжнародному ринку (відповідальне MG).

9. Допомога технічна (відповідальне - Міністерство розвитку регіонів (MRR)).

Крім того, як припускають деякі експерти, досі безпосередня участь польського уряду в інноваційному та бізнес-секторі призвела до кількох неефективних рішень (Gadomski, 17.3.2014). Інвестиції в інновації, які тісно контродьовані державними органами, $є$ не такими ефективними, як ті, що здійснені без участі політиків.

\section{Чехія}

Перша Національна інноваційна стратегія (НIC) [7] прийнята в 2004 році, після приєднання ЧР до ЄС (де інновації 
вважаються пріоритетним загальноєвропейським завданням в умовах зростаючого конкурентного тиску у світовій економіці), являе собою прорив порівняно 3 традиційним підходом до інноваційної подітики.

У НІС вперше у системній формі формулюється поняття інновацій, подаються інші визначення, що стосуються цієї проблематики (інноваційна фірма, інноваційне підприємництво, офсетові програми, передстартове фінансування, трансфер технологій, науково-технічний парк тощо). При цьому використовується дефініція документа Европейської Комісії COM (2003) 112: «Інновація є оновлення та розширення шкали виробів та послуг, а також пов'язаних 3 ними ринків, створення нових методів виробництва, поставок та дистриб'юції, запровадження змін в управлінні, організації та умовах праці, кваліфікації робочої сили».

У документі окреслено законодавчі та організаційні заходи, які вживаються в рамках ЕС з метою створення сприятливого інноваційного середовища як в Евросоюзі в цілому, так і в окремих країнах (Швеція, Фінляндія, Ірландія).

Відповідно до рекомендацій, які містилися в НІС, відповідні органи влади, наукові інституції та підприємницькі спілки підготували документ «Національна інноваційна політика ЧР на 2005-2010 рр.» (НІП), який був схвалений Урядом ЧР у червні 2005 року. Якщо НІС заклав, так би мовити, ідеологію інноваційного розвитку країни, то НІП став основою для практичної реалізації системи заходів щодо істотного поліпшення інноваційної діяльності.

На сьогодні високого рівня розвитку сучасна чеська наука досягла завдяки активній підтримці з боку держави та реформуванню наукової системи. Урядом ЧР було визначено цілі та пріоритети сучасної науково-інноваційної політики.

Основні питання, пов'язані з принципами, формою організації та управління науково-дослідною сферою, популяризацією чеської науки, урегульовуються нормативно-правовими документами. Серед них необхідно відзначити такі програми: 
«Національна науково-дослідна політика на 20092015 pp.» [8];

$>$ «Основні принципи діяльності уряду ЧР в галузі науки і техніки».

У цих нормативних актах чітко визначено роль науково-дослідної роботи в Чеській Республіці, функції держави і встановлено основні принципи, що регудюють діяльність уряду в галузі науки і техніки. У вересні 2011 р. чеський уряд схвалив такі нормативні акти: «Міжнародна стратегія конкурентоспроможності у Чеській Республіці», «Національна стратегія інновацій», підготовлені за участі Міністерства промисловості і торгівді, Національної економічної ради, а також експертів, учених, фахівців науково-дослідних установ Чехії, Академії ЧР. Метою Національної стратегії інновацій є підвищення ефективності чеської економіки. Науково-дослідну діяльність та розвиток інновацій визначено важдивою передумовою успішного економічного зростання країни.

Найважливіші питання щодо організації та управління чеської освіти та науки вирішуються в Міністерстві освіти, молоді та спорту - годовному органі в системі центральних органів виконавчої влади із забезпечення реалізації державної політики у сфері науки, науково-технічної, інноваційної діяльності та інтелектуальної власності. Певні функції в цій галузі також виконують й інші міністерства: охорони здоров'я, охорони навкодишнього середовища, сільського господарства й економіки.

Для проведення ефективної державної політики в науковій сфері Чехії функціонуе Рада з досліджень, розробок та інновацій, яка є головним консудьтативним органом уряду Чеської Республіки (ЧР). Рада складається із 17 членів - представників науково-дослідних установ, вищих навчальних закладів, Академії наук ЧР. Рада відіграє головну роль у виробленні стратегічних напрямів розвитку науково-дослідної діяльності у країні, подає пропозиції з розподілу бюджетних коштів на фінансування наукових програм і проектів, що схвалюються спільно з Міністерством фінансів. 
У результаті проведених реформ у чеській системі науки було зведено до мінімуму втручання держави в наукову роботу, спрощено механізм фінансування наукових досліджень із державного бюджету, стимульовано конкуренцію в галузі науки i техніки, підтримано інтеграцію наукових досліджень у діяльність університетів, зміцнено зв' язки між університетами і Академією наук ЧР, надано підтримку міжнародному науковому інноваційному співробітництву. Університети та АН ЧР отримали мождивість самостійно визначати пріоритетні напрями розвитку наукових досліджень, що стало поштовхом до формування конкурентоспроможного вищого освітнього закладу.

Базові положення інноваційної діяльності у вищій освіті і науці країн Вишеградської групи

Загальна стратегія розвитку науки та інновацій у Словаччині стала дороговказом для політиків і адміністраторів усіх рівнів. Крім університетів та науково-дослідних інститутів Словацької академії наук, основними ініціаторами та виконавцями плану інноваційних дій є новостворені центри перспективних технологій, центри передових досліджень і центри трансферу технологій, науково-технологічні парки та наукові центри. Вони тісно співпрацюють 3 великими й малими підприємствами, а також сприяють створенню нових інноваційних підприємств, яких на початковому етапі підтримуе держава. Спільна та узгоджена робота всіх ланок ланцюга інновацій, організована за планом дій та загадьною стратегією інноваційного розвитку, почала давати резудьтати.

\section{Розроблення стратегії інноваційного розвитку}

Одним з основних пунктів стратегії інноваційного розвитку є капітал для інновацій. Під цим розуміється ініціювання інноваційної діяльності, підтримка фондів капіталу $з$ підвищеним ризиком.

Наступними є інвестиції в інноваційні підприємства. Тут мається на увазі інвестування в дослідження та розвиток 
на окремих фірмах, надання технологічних кредитів, нові інвестиції з високим інноваційним потенціалом, заохочення інвестицій, що мають важливе значення для економіки, інвестиції в туристичні продукти та послуги, які мають не тільки регіональне значення.

Ще одним важливим пріоритетом стратегї є поширення (дифузія) інновацій. Сюди належить підтримка кооперативних зв'язків, що мають не тільки регіональне значення, підтримка низки проінноваційних інституцій у сфері бізнесу, які мають не тільки регіональне значення, підтримка осередків інноваційності, а також управління інтелектуальною власністю.

Політична підтримка співпраці університетів з бізнесом в Словаччині в основному відображена в декларативних стратегічних документах. Одним 3 таких документів $є$ «Довгостроковий план освітньої, науково-дослідної, творчої та іншої діяльності в університетах до 2014 року». Першим пріоритетом співпраці університетів з бізнесом в цьому документі названо поліпшення якості науки та освіти у словацьких вузах і зазначено, що сучасні підприємства будуть співпрацювати дише з тими академічними інституціями, які їі забезпечуватимуть.

Підтримка з боку уряду цього напряму спирається винятково на рекомендації і реалізується в основному через проекти, що фінансуються Европейським Союзом.

Так, для прикладу, Технічний університет м. Кошице має тісні зв'язки з місцевими і міжнародними промисловими партнерами. Співпраця з бізнесом реалізується, в першу чергу, через діяльність численних сучасних лабораторій, більшість яких була створена в рамках проектів 3 фінансуванням ЄС. Наприклад, кожна кафедра факультету електронної інженерії та інформатики має власну навчально-наукову лабораторію, яка забезпечує не тільки практичну складову навчальної програми, але й стає першим робочим місцем для багатьох студентів. Чимало лабораторій створено завдяки співпраці 3 найбільшими глобальними світовими виробниками IT техні- 
ки, мережного устаткування та надавачами IT сервісів: CISCO Telepresence, CISCO IPv6 Lab, Laboratoty IBM, T-System. B комерційних проектах лабораторій поруч працюють професори, студенти і представники організацій замовників. Більшість аспірантів працюють над дисертаціями разом зі своїми потенційними роботодавцями. Студенти заохочуються до складання зовнішніх іспитів з метою професійної сертифікації (наприклад, професійна сертифікація у сфері інформаційних технологій для роботи з продукцією Cisco Systems).

Розвивається дистанційне навчання (e-learning). Реалізуючи принцип «навчання впродовж життя», університет надає знання зі спеціалізованих комп'ютерних програм, що необхідні для роботи працівникам підприємств.

Університет намагається розвивати нові напрями діядьності, пов' язані з бізнесом. Створено університетський центр інновацій, трансферу технологій і захисту прав інтелектуальної власності UCITT. Адміністрація університету всіляко намагається мотивувати викладачів та науковців до пошуку комерційних проектів. Університет залишає для власних потреб 15\% прибутку за використання бренду, ризики та гарантії, решта розподіляеться між виконавцями. Таким чином, у структурі заробітної плати науково-педагогічних працівників вищого навчального закладу складова, отримана за рахунок різних проектів, становить до 40\%.

\section{Угориция}

Формування і розвиток інноваційного потенціалу, підвищення конкурентоспроможності серед університетів інших країн європейського простору - один із пріоритетів розвитку освітньої системи Угорщини.

Науково-обгрунтована інноваційна політика Угорщини базуеться на таких джерелах:

Співпраця між користувачами та/або виробниками. Нові гравці приєднуються до інноваційного процесуті, хто створюе форми співпраці на основі створених знань, які породжують нові можливості. 
Моду дьні конструкції, окремі частини яких можуть бути ініційованими самостійно, але в поєднанні вони утворюють єдину інноваційну систему. Комплекс технологічних інновацій у децентралізованій системі реалізований через нову підтримку в координації та сертифікації.

Інформаційні та комунікаційні технологіi, якщо їх вдається ефективно використовувати як єдиний інструмент для інновацій, то значною мірою сприяють трансформації діяльності.

Джерела генерації знань та інновацій, що грунтуються на описаних вище способах, наведені нижче (таблиця 1).

Таблиця 1

Джерела генерації знань та інновацій

\begin{tabular}{|c|c|c|c|c|}
\hline & 1 & 2 & 3 & 4 \\
\hline $\begin{array}{c}\text { Джерела } \\
\text { іннова- } \\
\text { цій }\end{array}$ & $\begin{array}{c}\text { Наукові до- } \\
\text { слідження }\end{array}$ & $\begin{array}{l}\text { Потреби } \\
\text { користу- } \\
\text { вачів і їх } \\
\text { запити }\end{array}$ & $\begin{array}{c}\text { Модуль- } \\
\text { ні систе- } \\
\text { ми }\end{array}$ & $\begin{array}{l}\text { Інформаційні } \\
\text { та комуніка- } \\
\text { ційні техноло- } \\
\text { гії як іннова- } \\
\text { ційний засіб }\end{array}$ \\
\hline $\begin{array}{c}\text { Важдиві } \\
\text { учасники } \\
\text { і контак- } \\
\text { ти }\end{array}$ & $\begin{array}{c}\text { Створені під- } \\
\text { приємства } \\
\text { університе- } \\
\text { тами }\end{array}$ & $\begin{array}{c}\text { Горизон- } \\
\text { тальні } \\
\text { спільноти }\end{array}$ & $\begin{array}{c}\text { Винахід- } \\
\text { ники і } \\
\text { модульні } \\
\text { кон- } \\
\text { структо- } \\
\text { ри }\end{array}$ & $\begin{array}{c}\text { IКТ - поста- } \\
\text { чальники, ке- } \\
\text { рівники, } \\
\text { співробітники, } \\
\text { зацікавлені } \\
\text { сторони, клі- } \\
\text { єнти }\end{array}$ \\
\hline $\begin{array}{c}\text { Тран- } \\
\text { сфер } \\
\text { знань у } \\
\text { промис- } \\
\text { довість }\end{array}$ & $\begin{array}{c}\text { Процеси і } \\
\text { продукти, } \\
\text { які мають } \\
\text { безпосереднє } \\
\text { значення для } \\
\text { подадьшого } \\
\text { розвитку нау- } \\
\text { кових знань }\end{array}$ & $\begin{array}{c}\text { Практичні } \\
\text { знання } \\
\text { про те, що } \\
\text { спільнота } \\
\text { може } \\
\text { досягти } \\
\text { значно } \\
\text { більше }\end{array}$ & $\begin{array}{c}\text { Інтегра- } \\
\text { тивне } \\
\text { знання. } \\
\text { Видима } \\
\text { інформа- } \\
\text { ція }\end{array}$ & $\begin{array}{c}\text { IКТ- } \\
\text { обробляються } \\
\text { за допомогою } \\
\text { систем, } \\
\text { кодифіковане } \\
\text { знання }\end{array}$ \\
\hline
\end{tabular}




\section{Знання та інновації в соціальному вимірі. Інновації, засновані на науці}

Організаційна модель вільного переміщення - це істотна риса знань, яка довела свою ефективність. Відповідно до цієї моделі в державному секторі наукових досліджень, промисловий сектор може вільно використовуватися. Це знання утворює дуже важдивий перехід до приватного наукового дослідження та інноваційної діяльності.

Результати суспільних знань збільшуються завдяки науковому дослідженню та індивідуальним інвестиційним деклараціям; як правило, це загальна база знань, яка для подальших досліджень надає більше переваг для компаній, що інвестують, ніж невигідне конкурентне становище рівного доступу до знань.

Сильні сторони угорської інноваційної системи:

високий ступінь відкритості економіки;

науково-дослідні досягнення високого класу, значні та ефективні досягнення у галузі фізики, математики, біології, хімії, медицини та інженерній науці;

наука, технології та інноваційна політика підкріплена відповідною законодавчою базою;

інститути та рамкові умови стрімко розвивалися і тепер допомагають у багатьох інноваційних відносинах.

Найбільш важдиві завдання компдексної інноваційної політики:

Угорщина має зміцнити фрагментовану інфраструктуру генерації знань - науково-досдідні інститути, університети і узгодити їх діяльність, щоб забезпечити відновлення і поліпшення їх здатності до реалізації значних цілей; внесок у досягнення стратегічних цілей національної економіки піддається вимірюванню;

при прийнятті рішення і його підготовці слід застосовувати суспільну та особисту відповідальність; 
для того, щоб розробити і впровадити довгострокову інноваційну стратегію стабільності - вертикальний напрям і горизонтальну координацію - повинні бути встановлені інституційні системи.

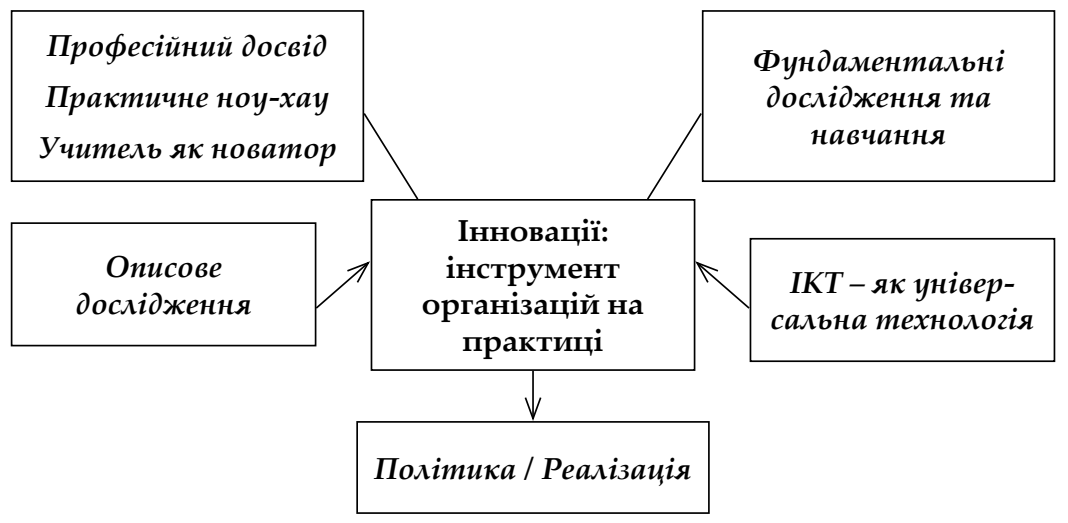

Отже, на нашу думку, можна виділити загальні позитивні риси вищенаведених РІС, досвід яких можуть застосувати на практиці і регіони України; це зокрема такі:

важлива роль науково-дослідних установ і університетів в інноваційній діяльності;

створення, за участю місцевих органів влади, організацій, які об’єднують в собі як підприємства, які займаються інноваційною діяльністю, так і наукові установи, які можуть виконувати роль генератора інновацій; значна увага приділяеться державній підтримці інноваційної діяльності підприємств малого та середнього бізнесу, зокрема через механізм податкових пільг;

можливість створення нових структур - промислових парків, інноваційних центрів, інкубаторів тощо;

запровадження програм з розвитку інновацій в тих галузях промисловості, в яких регіон має високий конкурентний потенціал;

тісна мережа зв' язків між суб'єктами інноваційної діяльності. 


\section{Польщза}

Ринкова комерціалізація нового знання у формі нових продуктів чи технологій є досить складним процесом з великим ризиком. Цей процес вимагає високих і різноманітних повноважень, що, як правило, перевищують можливості наукового середовища та бізнесменів. Водночас діяльність об'єднання «наука-економіка» стримується низкою бар'єрів, що ускладнюють спільну роботу над комерційними проектами. У цих умовах сформувалися спеціалізовані суб'єкти, які діють $з$ метою трансферу технології з науки до економіки. Такі суб'єкти можуть називатися: центр трансферу технологій, технологічний центр, технологічне агентство, інкубатори інновацій, технологічний парк тощо. Для цієї категорії установ 3 відмінними в багатьох аспектах цілями, організаційно-правовою формою, структурою тощо прийнято вживати загальне визначення - центри інновацій, інституції-посередники, інфраструктура трансферу технологій.

Тому на практиці центри інновацій та підприємництва вважаються суб'єктами, що реалізують програми підтримки у сфері інноваційності та підприємництва в широкому розумінні цих слів.

\section{Така діядьність відбувається у формах:}

поширення знань і вмінь шляхом надання консультацій і проведення навчань, збирання й поширення інформації, надання допомоги у трансфері технологій у рамках діяльності центрів трансферу технологій;

надання підтримки під час створення нових підприємств у рамках наукових організацій і ВН3, що засновуються студентами, випускниками, аспірантами й науковими працівниками в так званих пре-інкубаторах та академічних інкубаторах підприємництва;

надання комплексних послуг у певному місці за визначеним стандартом, в оточенні наукових інституцій, з метою підтримки започаткування інноваційної господарчої діяльності (інноваційні інкубатори, інкубатори підприємництва, технологічні центри); 
створення місць концентрації підприємств (кластерів) та інноваційного середовища шляхом об'єднання в рамках визначеної території послуг для бізнесу та різноманітних форм допомоги для технологічних фірм у рамках технологічних, наукових і промислово-технологічних парків;

надання початкової фінансової підтримки (seed i startup) у формі пара-банкових позичкових і гарантійних фондів; важливим ринковим доповненням цієї категорії є комерційно орієнтовані фонди венчурного капіталу (venture capital).

Центри інновацій є суттевим елементом кожной сучасної інноваційної системи крайни, яка розбудовуе основи економіки, базовані на знаннях. Вони відповідають за побудову платформи діалогу та співпраці світу науки й бізнесу, створюючи умови _для ефективного трансферу інформації, знань і технодогій. Їх активність вкдючає:

$>$ ініціювання та організацію співпраці всіх партнерів, необхідних для ефективної реалізації інноваційного процесу;

визначення інноваційних потреб фірм і комерційних можливостей у рамках наукових організацій;

удосконалення механізмів трансферу технодогій; створення необхідних для економічного розвитку партнерства різних приватних і публічних суб'єктів;

реалізацію програм підтримки в регіонах.

На основі предмета діяльності, місій, цілей і неприбуткового характеру (нон-профіт), у польських умовах до організацій підтримки можна віднести такі види суб'єктів:

організаційно та фінансово самостійні суб'єкти науково-дослідних організацій, активні в сфері комерціалізації нових технологій, такі, що надають підтримку розвиткові місцевої (регіональної) економіки. 
Спроможність системи підтримки є функцією визначення потреб для розвитку та будування на ії основі програм, що створюють можливість оптимального використання обмежених ресурсів. Це зокрема:

фонди та асоціації, а також створені ними суб'єкти, що реалізують програми розвитку підприємництва та трансферу технологій;

суспідьно-приватні товариства, засновані з ініціативи та при великій організаційній та фінансовій участі державної й місцевої влади, що виконують діяльність, спрямовану на підтримку розвитку, не зобов'язані до генерування прибутків 3 метою розподілу останніх між пайовиками (агентствами місцевого й регіонального розвитку);

організаційно та фінансово самостійні суб'єкти місцевої адміністрації націлені на підтримку інноваційності та розвиток місцевої економіки.

Роль центрів інновацій у сучасних економіках динамічно зростає. Це пов'язано з відходом від дінійної моделі інноваційного процесу, де домінували акти купівді-продажу технологічних рішень. Сьогодні трансфер технологій $є$ інтерактивним процесом, у якому присутні різноманітні петлі зворотних зв'язків між передавачами та приймачами інформації. Це виняткова форма процесу спілкування, яка вкдючае різноманітні форми поширення інновацій та технічної освіти. Сьогодні традиційні форми трансферу доповнюються такими аспектами: створення малих технологічних фірм та підтримка інноваційних заходів у МСП; технологічний консалтинг і посередництво, інформування про нові технології; ініціювання мереж підтримки, співпраці та кооперації.

Зазвичай ініціатори змін, особи, які пробують упровадити будь-які нові рішення до суспільного й господарського життя, зіштовхуються з різноманітними перешкодами - ментальними, фінансовими, політичними, організаційними. 
Одним з очевидних ефектів було створення Подьської асоціації організаторів бізнес-інкубаторів та інноваційних центрів, яка розпочала інформаційну, пропагандистську, консалтингову, навчальну діяльність та добіювання.

Сьогодні, після 15-ти років набуття досвіду, відбувається повільна консодідація польської моделі інституційної підтримки інноваційної діяльності. Роль центрів інновацій знайшла своє втілення в Національному плані розвитку та в інших програмних документах щодо господарського розвитку країни.

Центри інновацій є пріоритетним інструментом реалізації Секторної операційної програми (СОП) - зростання конкурентоспроможності економіки.

Розвиток технологічних парків та інкубаторів безпосередньо записаний у пріоритеті 1, діï 3: «Створення сприятдивих умов ддя розвитку підприємств». Як підтримку аналізованих ініціатив можемо розглядати інші дії. Наприклад, (1) «Зміцнення організацій, що підтримують діяльність підприємств» і (4) «Зміцнення співпраці між науково-дослідницькою сферою та економікою». Тут, передусім, ідеться про розвиток послуг підтримки бізнесу. Проекти можуть бути фінансованими 3 таких джерел: СОП «Розвиток юдських ресурсів», пріоритет 2 - «Розвиток суспільства, що базується на знаннях», дія 3 -«Розвиток кадрів сучасної економіки та підприємництва»; 3 «Інтегрованої операційної програми регіонального розвитку» (ІОПРР), наприклад, пріоритет 1- «Розбудова та модернізація інфраструктури, що служить зміцненню конкурентоспроможності регіонів», дія 5 - «Інфраструктура інформаційного суспільства», пріоритет 2 -«Зміцнення регіональної економічної бази та людських ресурсів», дія 3 - «Розвиток кадрів регіональної економіки», дія 4 - «Регіональні інноваційні стратегії», пріоритет 3 - «Місцевий розвиток» [9].

У другій половині 2005 року кількість активних центрів інновацій становила 77, натомість кількість реалізованих ініціатив - 86. У порівнянні з 2004 роком відбулося 60-відсотко- 
ве збільшення кількості суб'єктів цього типу. Так, висока динаміка має кілька джерел:

розвиток нової категорії центрів - академічних інкубаторів підприємництва, більшість 3 яких почала свою діяльність наприкінці 2004 - на початку 2005 років;

> у сфері підтримки інноваційності почали діяти Наукові одиниці розвитку (НОР) та професійні об'єднання (Вища технічна організація та воєводські клуби техніки та раціоналізаціі);

зростання активності недержавних ВН3;

$>$ реалізація проектів пріоритету 1, дії 3 - «Створення сприятливих умов для розвитку підприємств» у рамках Секторної операційної програми «Зростання конкурентоспроможності економіки».

Більшість нових центрів були створені в результаті реалізації нових завдань суб'єктами, ринкове становище яких стало стабільним. Нові інституції є винятками. Низка аналізованих центрів діє у формі проектів з обмеженою організаційною та технологічною самостійністю. У кількох випадках стикаємося зі специфічною ситуацією дублювання центрів, наприклад, у технологічному парку, що розвивається, діє технологічний інкубатор або ж академічний інкубатор підприємництва діє в центрі трансферу технологій.

Протягом останніх років важливим елементом підтримки розвитку інфраструктури трансферу технологій була діяльність Польського агентства розвитку підприємництва (ПАРП), а саме:

опрацювання аналітичних звітів щодо можливості впровадження, звітів про вплив на середовище та бізнес-планів для 13-ти промислових і промислово-технологічних парків (завдання, реалізовані спільно 3 Агентством розвитку промисловості);

$>$ допомога у створенні й керуванні 23-ма центрами трансферу технологій, технологічними парками та інкубаторами. 
Таблиця 2

\begin{tabular}{|c|l|c|c|}
\hline $\begin{array}{c}\text { № } \\
\mathbf{\Pi} / \mathbf{\Pi}\end{array}$ & $\begin{array}{c}\text { Типи центрів інновацій } \\
\mathbf{y ~ П о л ь щ і ~}\end{array}$ & Діючі & $\begin{array}{c}\text { У процесі створен- } \\
\text { ня (оціночні дані) }\end{array}$ \\
\hline 1 & Центри трансферу технологій & 44 & 40 \\
\hline 2 & Технологічні інкубатори & 7 & 15 \\
\hline 3 & $\begin{array}{l}\text { Академічні інкубатори під- } \\
\text { приємництва }\end{array}$ & 18 & 22 \\
\hline 4 & $\begin{array}{l}\text { Технологічні парки (в тому } \\
\text { числі науково- та промисло- } \\
\text { во-технологічні парки) }\end{array}$ & 8 & 19 \\
\hline & Загалом & 77 & 86 \\
\hline
\end{tabular}

Джерело: [6]

У результаті доопрацьовано низку проектів: технологічних і промислово-технологічних парків, технологічних та академічних інкубаторів. Важливою формою діяльності, що об'єднує середовища інституцій підтримки в окремих воєводствах, є розроблення регіональних інноваційних стратегій. У майбутньому на регіональному рівні, який координується Маршалківськими управліннями, очікується зростання ролі механізмів підтримки та числа авторитетних осіб, котрі приймають рішення.

Польські центри інновацій функціонують у різних організаційно-правових формах. Найчастіше стикаємося із суб'єктами сектора R\&D (43,2\%), звідси 72\% становдять академічні загальновузівські, міжфакультетські центри або центри факультетів.

Протягом найближчих років очікується збереження динаміки створення нових центрів у зв'язку з такими передумовами:

1) записані в Ліссабонській стратегії пріоритети країн ЕС ведуть до того, що використання Структурних Фондів дедалі більше націлене на побудову економіки, базовану на знаннях, у тому числі на розвиток орга- 
нізацій та механізмів трансферу знань і технологій до малих і середніх підприємств;

2) розвиток нових форм активності ВНЗ; зростання конкуренції змушуе їх до розширення сфери традиційних функцій ВНЗ (дослідницької і дидактичної), включаючи до них діяльність у сфері підприємництва й трансферу технологій;

3) реструктуризація Польської академії наук і наукових одиниць розвитку.

4) пошук академічними установами додаткових джерел фінансування, розширення сфери завдань бюро патентів, мереж контактних пунктів і центрів кар'єри;

5) розширення сфери завдань і поступова модифікація частини діючих центрів підприємництва в технологічні центри, що реалізують програми підтримки інновацій та трансферу технологій до МСП.

Для зміцнення діючих і створення нових організацій підтримки та розвитку підприємництва кдючове значення має діяльність у таких сферах:

1. Створення програм підтримки інноваційності, підприємництва та розвитку МСП на національному, регіональному й районному рівнях, усюди, де для найефективніших інституцій є кошти (що видідяються в рамках конкурсів).

2. Поліпшення управдіння та участі в діючих програмах підтримки.

3. Розвиток освіти для консультантів бізнесу й експертів трансферу технологій; навчання й удосконалення колективів у сфері організації трансферу технологій та охорони інтелектуальної власності: післядипломне навчання, аспірантура, навчальні поїздки та стажування за кордоном у відомих ВНЗ США та Европи (а також китайських, тайванських та ізраїльських).

4. Підвищення рівня вмінь опрацювання й управління програмами трансферу та комерціалізації технологій. 
5. Розвиток інфраструктури лобіювання в регіонах, на національному рівні, а також при европейських комісіях; опрацювання та інформування про «історії успіху».

6. Розвиток таких регіональних систем інновацій, як мережі співпраці адміністрацій, науково-дослідних інституцій, центрів інновацій та підприємництва.

7. Допомога в підготовці аналітичних звітів про мождивості виконання і складання бізнес-планів для нових центрів та забезпечення їх рівномірного розвитку по всій країні.

8. Розвиток міжнародних контактів і співпраці.

9. Розробка системи моніторингу діядьності організацій та програм підтримки.

Успішна діяльність гравців інноваційного поля на регіональному рівні передбачає:

значну роль у втіленні на місцях плану національної інноваційної політики;

активну участь у розвитку регіону;

важливу роль у реалізації регіональної інноваційної стратегії;

$>$ співробітництво та кооперацію регіональних технодогічних та індустріальних кластерів;

участь у спільних технологічних і наукових проектах; оптимальне використання центрального й місцевого бюджету для економічного розвитку;

$>$ узгоджену роботу державних органів влади, відповідальних за розвиток і реалізацію національної наукової та інноваційної політики (міністерств, національних агентств, місцевих адміністрацій тощо);

участь у виконанні національних програм розвитку;

участь у пошукових наукових дослідженнях.

У Польщі, у Гданьскому інституті ринкової економіки було проведено дослідження регіональних інноваційних 
систем (РІС). Згідно 3 ним, можна виділити такі їх сильні сторони:

діяльність, спрямована на фінансову (в основному зі структурних фондів) підтримку інноваційної діяльності;

наявність фінансових інструментів для підтримки $\mathrm{H} \lambda Д \mathrm{KP}$;

зростаючу обізнаність та інноваційну культуру підприємств, установ та місцевих органів влади;

зростання кількості інноваційно активних підприємств (збільшується рівень витрат на НД,ДКР та рівень зайнятості в цій сфері);

зростання кількості установ 3 підтримки інновацій та установ 3 підтримки бізнесу;

високий конкурентний потенціал фірм у деяких (традиційних для Польщі) галузях: харчовій промисловості, галузі машинобудування та деревообробної промисловості;

збільшення кількості товарів і послуг інноваційного характеру;

високий рівень активності бізнес-середовища;

поліпшення доступу фірм до трансферу технологій на регіональному, національному та міжнародному рівнях;

зростання частки експорту з високим ступенем переробки товарів;

$>$ реалізація європейських проектів, пов'язаних 3 інноваційним розвитком;

динамічний розвиток сектора малого і середнього бізнесу.

Між тим необхідно також окреслити деякі слабкі сторони РІС Польщі:

кваліфікація деяких співробітників установ НДДКР є занадто низькою з точки зору їх здатності брати участь у підвищенні ефективності інноваційної діяльності; 
обмежені мождивості співпраці $з$ науково-дослідними установами та іншими підприємствами; застарілі технології та технічне обладнання багатьох підприємств;

обмежена кількість стимулів для інноваційної діяльності (без значних податкових пільг або інвестиційної підтримки);

обмеженість власних коштів підприємств для інвестування в інноваційну діяльність.

\section{Чехія}

Наприкінці XX - на початку XXI стст. наукова система Чехії намагалась адаптуватись до політичних та економічних змін у країні.

Сьогодні уряд Чехії створює умови для надання ефективної державної підтримки системі НДДКР, що задоводьняє потреби економіки країни на сучасному етапі адаптації до стандартів Европейського Союзу. Це зводить до мінімуму втручання держави в наукову роботу, спрощуе механізми фінансування 3 державного бюджету, стимулюе конкуренцію в галузі науки і техніки, підтримує інтеграцію наукових досліджень у діяльність університетів, зміцнює зв'язки між університетами й Академією наук, а також надає підтримку міжнародній науково-інноваційній співпраці [10].

За останні роки державні асигнування на науково-дослідну діяльність у Чехії виділяються в основному для неуніверситетських наукових центрів. Основні фінансові надходження, направлені на розвиток чеської науки, розподіляються між Академією наук ЧР і Міністерством освіти, молоді та спорту. Невелика частина коштів 3 державного бюджету надходить до Міністерства промисловості і торгівлі, Міністерства охорони здоров'я, Міністерства сільського господарства, Міністерства охорони навколишнього середовища, Міністерства транспорту для фінансування цільових індустріальних програм і наукових проектів, що підвищують конкурентоспроможність чеської економіки. У цілому в 2010 р. фінан- 
сові надходження на розвиток науково-дослідної діяльності в Чехії становили близько 1,56 \% ВВП (з цих коштів 49 \% асигновано приватним сектором, 41\% - державою, 10\% - закордонними інвесторами).

Протягом останніх років Чехія дедалі більше приділяе уваги розвитку науки, однак тільки за рахунок державного бюджету наука не може повноцінно розвиватись, тому фінансування наукових досліджень здійснюється через впровадження системи грантів. Урядом Чехії, університетами та Академією наук ЧР створено фонди, що фінансують фундаментальні дослідження. Окремі наукові дослідження фінансуються агентствами, які створені міністерствами і відомствами, великими промисловими підприемствами, що зацікавлені в наукових розробках. Важливу роль у розподілі коштів відіграє Агентство 3 технологій (засноване у 2009 р.), що підтримуе програми, прикладні соціальні наукові проекти, дослідно-конструкторські розробки, інноваційні дослідження тощо.

У Чехії великого значення набули зв'язки науки 3 промисловістю, впровадження наукових розробок у виробництво. У початковий період реформ передбачалось, що промислові науково-дослідні установи трансформуються в регіональні технологічні парки. Дослідницькі організації заснували Асоціацію наукових парків, яка мала створити базу для реорганізації науково-дослідних інститутів. Для впровадження технологій у виробництво було створено Асоціацію трансферу технологій й обміну. У політичних колах ця позиція не знайшла підтримки, у результаті чого 105 наукових установ були приватизовані й у своїй діяльності стали менше займатися науковими дослідженнями [11]. Були запроваджені державні програми «Парк» і «Трансферт», які надавали реальну підтримку малим і середнім підприємствам. Також відіграють важливу роль у фінансуванні наукових проектів місцеві бюджети.

Академічний сектор переорієнтувався на технічні науки і прикладні дослідження. Це створило можливість налагоди- 
ти більш тісні контакти 3 керівництвом наукових і технологічних парків. Науково-технологічні парки виникли і в самій Академії наук, хоча вони виявидися менш продуктивними, ніж створені на базі промислових підприємств.

Поступово сформувалися зв'язки між університетами й промисловими фірмами. Вони набули характеру дослідницьких експертиз нових технологій і наукових розробок, що застосовувались у виробництві. Однак в університетах Чехії така практика займає невеликий відсоток і у фінансовому відношенні пріоритет надається саме освіті, а не науковим дослідженням.

Серед найвідоміших університетів Чехії слід відзначити:

- Карловий університет;

- Університет економіки (VSE) (м. Прага);

- Університет фінансів та адміністрування (м.Прага);

- Університет ім. Т. Г. Масарика (м. Брно);

- Університет Західної Богемї (м. Пльзень);

- Вищу гірничу школу - технічний університет (м. Острава);

- Університет ім. Ф. Палацького (м. Оломоуц);

- Чеський політехнічний університет (м. Прага);

- Менделівський сільськогосподарський та лісотехнічний університет (м. Брно);

- Чеський сільськогосподарський університет (м.Прага);

- Університет Тамаша Бата (м. 3лін);

- Університет Градец Кралова (м. Градец Кралове).

Усього в Чехії понад 35 вищих навчальних закладів. При університетах діють установи, які ведуть науково-дослідну діяльність. Зокрема, в університеті ім. Т. Г. Масарика функціонують: Міжнародний інститут політологіі, Інститут обчислювальної техніки, у Карловому університеті діють Інститут політології і міжнародних відносин, Інститут економіки, Інститут соціології, Інститут журнадістики тощо.

За результатами дослідження, проведеного у 2010 р. іспанською науково-дослідною групою Scimago, було визначено рейтинг Академіі наук ЧР і Карлового університету, згідно 3 
яким ці установи займають почесне п'яте і шосте місця серед науково-дослідних інститутів та університетів Центральної і Східної Европи. У цілому рейтинг охоплюе 172 науково-дослідних інститути і університети зі Східної Европи та 2833 установи у всьому світі. У світовому рейтингу АН ЧР і Карловий університет зайняли 97 та 231 місце відповідно [12].

Основу для розвитку сучасної науково-технічної співпраці між Чеською Республікою та Україною було закладено підписанням угоди між урядом ЧР та Кабінетом Міністрів України про економічне, промислове та науково-технічне співробітництво, угоди про співробітництво в галузі культури між Міністерством культури України та Міністерством культури ЧР на 2012-2014 рр., угоди про співробітництво в галузі освіти та науки на 2012-2015 рр. між Міністерством освіти і науки, молоді та спорту України і Міністерством освіти, молоді та спорту ЧР. Договірно-правова база з питань науково-технічного співробітництва між Чехією й Україною достатньо широка та охоплює різноманітний спектр взаємодії сторін у зазначеній галузі. Науково-технічне співробітництво між Україною та ЧР передбачає спільні науково-технологічні та науково-досдідні проекти; обмін науковцями, фахівцями, дослідниками та експертами з метою виконання наукових програм і проектів; обмін науковою і технічною інформацією, документацією, а також лабораторними зразками та обладнанням; організацію та проведення спільних наукових конференцій, симпозіумів, семінарів, виставок. Крім того, діє низка прямих угод про співробітництво між вищими навчадьними закладами України та Чехії.

Співробітництво в галузі освіти відбувається також по лінії обміну студентами, аспірантами та викладачами вищих навчальних закладів обох країн.

Характерною рисою міжнародної співпраці наукових організацій Чехіі став перехід на багатосторонню форму співробітництва з іноземними науковими установами. Особливо інтенсивно почала розвиватись міжнародна наукова співпраця з європейськими країнами. Завдяки підписаній 
угоді про асоційоване членство країна отримала повний доступ до всіх програм і заходів Европейського Союзу в галузі науки і техніки.

Слід наголосити, що головним чинником інноваційного процесу в країні є промислові розробки. При цьому пріоритетними вважаються такі високотехнологічні галузі, як автомобілебудування та авіабудування, інформаційні, телекомунікаційні, нано- і біотехнологіі. Цільові дослідницькі програми здійснюють 22 державні організації та відомства. Діє Центр авіаційних і космічних досліджень.

Значну роль у забезпеченні інноваційного розвитку країни відведено установам Чеської академї наук та вищим навчальним закладам. В інститутах і університетах створено спеціалізовані технологічні центри, які надають послуги підприємцям в області трансферу технологій. Ці центри та інші спеціалізовані дослідницькі організації взаємодіють 3 промисловими підприємствами, створюючи консорціуми для роботи над конкретними проектами.

На особливу увагу заслуговуе практика створення так званих інноваційних підприємницьких інкубаторів та науково-технологічних парків, яка набула широкого застосування в країні. Програми інноваційних інкубаторів надають підприємницьким суб'єктам низку фінансових та інших інструментів та послуг підтримки. Управління програмами здійснюється менеджментом інноваційних інкубаторів. У випадку науково-технологічних парків йдеться про великі проекти, які надають адміністративні та лабораторні приміщення в оренду підприємницьким та державним структурам, вищим навчальним закладам, а також малим інноваційним фірмам. Обсяг послуг тут менший, ніж в інкубаторах, але орендатори можуть використовувати вигоди високого рівня концентрації інноваційних суб'єктів в одному місці. За результатами міжнародного дослідження консалтингової компанії «Ernst\&Young», нині Чехія входить в десятку країн, найбільш привабливих для вкладення інвестицій у розвиток науково-технологічних парків. 


\section{Список використаних джерел}

1. Угода про асоціацію між Україною та Европейським Союзом [Електронний ресурс]. - Режим доступу: http://www.kmu. gov.ua/kmu/control/ uk/publish/article?art_id=246581344\&cat_ id $=223223535$

2. CommunityInnovationSurvey(CIS)[Електроннийресурс].-Режим доступу: http://www.cso.ie/en/media/csoie/releasespublications/ documents/multi-sectoral/2010/comminn0810/pdf

3. European Innovation Scoreboard [Електронний ресурс]. - Режим доступу: http://ec.europa.eu/growth/industry/innovation/factsfigures/scoreboards/ files/ius-2015_en.pdf

4. Long-term Plan for the Science and Technology Policy of the Slovak Republic by 2015. Bratislava [Електронний ресурс]. - Режим доступу:https://www.vedatechnika.sk/SK/VedaATechnikaVSR/ Certifikacia/Documents/Long_Term_Plan_by_the_year_2015.pdf

5. Innovation Policies in the Visegrad Countries [Електронний ресурс].- Режим доступу: http://ibs.org.pl/projekty /fi les/Visegrad/ Publication.pdf

6. Бонковскі А. Інструменти підтримки інноваційності малих і середніх підприємств: досвід Подьщі та Європейського Союзу / Александр Бонковскі, Міхал Клепка, Кшиштоф Матусяк, Ежи Стшелєц, Кшиштоф Засядли. - Познань, 2005. - 186 с.

7. Národní inovační strategie České republiky. (National Innovation Strategy of the Czech Republic). Prague. [Електронний ресурс]. Режим доступу: http://www.msmt.cz/ index.php?lang=2

8. Národní politika VaVaI v ČR na léta 2009 až 2015 s výhledem do roku 2020. (The National Policy of Research, Development and Innovations for the period 2009-2015 with an outlook to 2020). Prague. [Електронний ресурс]. - Режим доступу:http://www. vyzkum.cz/storage/att/316EDE80438A49F64BF884 897F06F6C1/ Narodni\%20politika\%20vyzkumu\%20vyvoje\%20a\%20inovaci\%20 CR\%20na\%20leta\%202009_2015.pdf

9. Національний план розвитку 2004-2006 рр., ухвалений Радою Міністрів Польщі 14 січня 2003 року, скоригований відповідно до рішення Ради Міністрів з 11 лютого 2003 року, Варшава, лютий 2003, С. 91-125.

10. Filacek A. Social Sciences and Humanities in Czech Republic // Theory of Science. - 2004. - Vol. 24, N 1. - P. 5-34. 
11. Водопьянова Е. Страны Центральной и Восточной Европы: наука в пути / Е. Водопьянова // Мировая экономика и международные отношения. - 2000. - № 10. - С. 71-77.

12. Академия наук Чехии и Карлов университет признаны лучшими в Восточной Европе - Scimago [Электронный ресурс]. - Peжим доступа: http://www.novoya.com/info/1500.html 